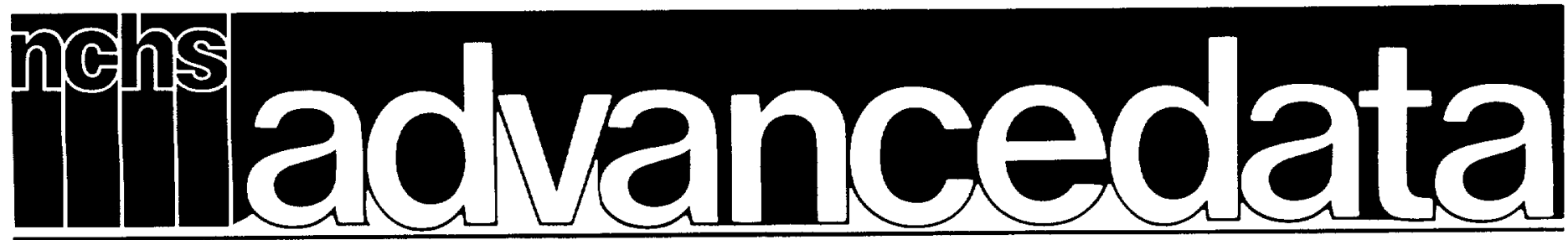

From Vital and Health Statistics of the National Center for Health Statistics

Number 104 - February 11, 1985

\title{
Fecundity and Infertility in the United States, 1965-82
}

\author{
by William D. Mosher, Ph.D., and William F. Pratt, Ph.D., Division of Vital Statistics
}

In 1982, about half of all American married couples with wives in the childbearing ages were currently sterile or had some childbearing impairment. Almost 8 million of these couples were voluntarily sterilized because they had had all the children they wanted. However, another approximately 6 million couples were unable or unlikely to have additional births, including about 1.4 million couples who were childless. These and related statistics on fecundity and infertility in the United States are from the National Survey of Family Growth, most recently conducted in 1982 by the National Center for Health Statistics.

This report presents, for the first time, preliminary nationwide statistics on the fecundity status of all women of reproductive age in the United States, regardless of marital status, and reports the latest data on trends in fecundity and infertility among married couples. The data on currently married women in this report update statistics published in a previous report. ${ }^{1}$ The data for 1976 and 1982 were collected in Cycles II and III of the National Surveys of Family Growth (NSFG's); the data for 1965 are from the 1965 National Fertility Study conducted by Princeton University. ${ }^{2}$

The 1982 NSFG was based on personal interviews with a national sample of 7,969 women in the childbearing ages (15-44 years of age) in the noninstitutionalized population of the conterminous United States. Between August 1982 and February 1983 interviews were conducted with 3,201 black women and 4,768 women of races other than black. The interview focused on the respondent's fecundity (or physical ability to have children); past and current use of contraception; marital and pregnancy history; use of family planning and infertility services; labor force participation; and a wide range of social, economic, and demographic characteristics.

\section{The Concept of Fecundity Status}

The respondent's physical ability to have children was measured by her answers to a series of questions, not by a medical examination. The purpose of this series of questions was to classify couples into three major groups: surgically sterile (impossible to have a baby); impaired fecundity (nonsurgically sterile or difficult or dangerous to have a baby); and fecund (no known physical problem). The questions included the following:

As far as you know, is it possible or impossible for you ... to get pregnant (again)?

As far as you know, is there any problem or difficulty for you ... to conceive or deliver a(nother) baby?

In these questions, the words "as far as you know" are important. Many women who have never tried to become pregnant do not know whether they have a fecundity impairment. Some women who reported that they did not know of any physical problems nonetheless have had long periods of time in which they did not conceive although they used no contraception. A few women may be classified as having fecundity problems because of underreporting of either contraceptive use or pregnancies, but there is no evidence that this underreporting has a significant effect on the estimates presented here. ${ }^{3}$ Finally, while some women with fecundity problems subsequently may have children, their reduced capacity for childbearing has an impact on the nation's birthrate and on the estimates of couples needing medical services to improve their chances of childbearing.

The category "surgically sterile" is divided into two subgroups: contraceptively and noncontraceptively sterile. The category "contraceptively sterile" consists of women or their current husbands who have had a sterilizing operation (tubal ligation, hysterectomy, or vasectomy) at least partly because they had had all the children they wanted. Table 1 shows that in 1982, 17 percent of all women 15-44 years of age were contraceptively sterile, including 1 percent of never married women, 28 percent of currently married women (or their husbands), and 20 percent of formerly married women. Not surprisingly, in each marital status category the percent contraceptively sterile was much higher for women with children (parity 1 or more) than for childless women (parity 0 ). 
Table 1. Number of women $15-44$ years of age and percent distribution by fecundity status, according to marital status, parity, and age: United States, 1982

[Preliminary statistics based on a sample of the female population of the conterminous United States. See Technical notes for estimates of sampling variability and definitions of terms]

\begin{tabular}{|c|c|c|c|c|c|c|c|c|c|}
\hline \multirow[b]{2}{*}{$\begin{array}{c}\text { Marital status, parity. } \\
\text { and age }\end{array}$} & \multirow[b]{2}{*}{$\begin{array}{c}\text { All } \\
\text { women }\end{array}$} & \multirow[b]{2}{*}{ Total } & \multicolumn{2}{|c|}{ Surgically sterile } & \multicolumn{4}{|c|}{ Impaired fecundity } & \multirow[b]{2}{*}{ Fecund } \\
\hline & & & Contraceptive & Noncontraceptive & $\begin{array}{c}\text { All } \\
\text { impaired }\end{array}$ & $\begin{array}{l}\text { Non- } \\
\text { surgically } \\
\text { sterile }\end{array}$ & Subfecund & $\begin{array}{l}\text { Long } \\
\text { interval }\end{array}$ & \\
\hline $\begin{array}{l}\text { MARITAL STATUS } \\
\text { AND PARITY }\end{array}$ & $\begin{array}{l}\text { Number in } \\
\text { thousands } \\
\end{array}$ & \multicolumn{8}{|c|}{ Percent distribution } \\
\hline All women . . . . . . . . . & 54,099 & $\overline{100.0}$ & 17.4 & 7.8 & 8.2 & 1.6 & 5.4 & 1.2 & 66.5 \\
\hline $\begin{array}{l}\text { Parity } 0 \ldots \ldots \ldots \\
\text { Parity } 1 \text { or more } \ldots \ldots\end{array}$ & $\begin{array}{l}22,941 \\
31,158\end{array}$ & $\begin{array}{l}100.0 \\
100.0\end{array}$ & $\begin{array}{r}1.4 \\
29.2\end{array}$ & $\begin{array}{r}1.7 \\
12.4\end{array}$ & $\begin{array}{l}8.4 \\
8.1\end{array}$ & $\begin{array}{l}2.5 \\
1.0\end{array}$ & $\begin{array}{l}5.2 \\
5.6\end{array}$ & $\begin{array}{l}0.7 \\
1.5\end{array}$ & $\begin{array}{l}88.5 \\
50.2\end{array}$ \\
\hline \multicolumn{10}{|l|}{ Never married } \\
\hline All parities . . . . . . . . & 19.162 & 100.0 & 1.3 & ${ }^{*} 0.8$ & 4.1 & 1.0 & 3.0 & 0.1 & 93.8 \\
\hline $\begin{array}{l}\text { Parity } 0 \ldots \ldots \ldots \\
\text { Parity } 1 \text { or more } \ldots \ldots\end{array}$ & $\begin{array}{r}16.693 \\
2,469\end{array}$ & $\begin{array}{l}100.0 \\
100.0\end{array}$ & $\begin{array}{rl}* & 0.3 \\
7.9\end{array}$ & $\begin{array}{l}* 0.4 \\
* 3.8\end{array}$ & $\begin{array}{r}3.7 \\
* 6.4\end{array}$ & $\begin{array}{l}1.0 \\
0.8\end{array}$ & $\begin{array}{l}2.6 \\
5.6\end{array}$ & $\begin{array}{l}0.1 \\
0.0\end{array}$ & $\begin{array}{l}95.6 \\
81.8\end{array}$ \\
\hline \multicolumn{10}{|l|}{ Currently married } \\
\hline All parities $\ldots \ldots \ldots \ldots$ & 28,231 & 100.0 & 27.8 & 11.0 & 10.5 & 2.0 & 6.3 & 2.1 & 50.7 \\
\hline $\begin{array}{l}\text { Parity } 0 \ldots \ldots \ldots \\
\text { Parity } 1 \text { or more } \ldots \ldots\end{array}$ & $\begin{array}{r}5,098 \\
23,134\end{array}$ & $\begin{array}{l}100.0 \\
100.0\end{array}$ & $\begin{array}{l}* 4.6 \\
33.0\end{array}$ & $\begin{array}{l}* 5.3 \\
12.3\end{array}$ & $\begin{array}{r}21.7 \\
8.0\end{array}$ & $\begin{array}{l}7.2 \\
0.9\end{array}$ & $\begin{array}{r}11.8 \\
5.1\end{array}$ & $\begin{array}{l}2.6 \\
2.0\end{array}$ & $\begin{array}{l}68.4 \\
46.7\end{array}$ \\
\hline \multicolumn{10}{|l|}{ Formerly married } \\
\hline All parities . . . . . . . . & 6.706 & 100.0 & 19.9 & 14.4 & 10.7 & 1.9 & 8.7 & 0.0 & 54.9 \\
\hline $\begin{array}{l}\text { Parity } 0 \ldots \ldots \\
\text { Parity } 1 \text { or more } \ldots \ldots\end{array}$ & $\begin{array}{l}1,150 \\
5,556\end{array}$ & $\begin{array}{l}100.0 \\
100.0\end{array}$ & $\begin{array}{l}* 4.2 \\
23.2\end{array}$ & $\begin{array}{r}* 4.1 \\
16.6\end{array}$ & $\begin{array}{r}* 16.6 \\
* 9.4\end{array}$ & $\begin{array}{l}2.1 \\
1.8\end{array}$ & $\begin{array}{r}14.3 \\
7.6\end{array}$ & $\begin{array}{l}0.1 \\
0.0\end{array}$ & $\begin{array}{l}75.1 \\
50.8\end{array}$ \\
\hline \multicolumn{10}{|l|}{ AGE } \\
\hline $\begin{array}{l}15-19 \text { years } \ldots \ldots \ldots \ldots \\
20-24 \text { years } \ldots \ldots \ldots \ldots \\
25-29 \text { years } \ldots \ldots \ldots \ldots \\
30-34 \text { years } \ldots \ldots \ldots \ldots \\
35-39 \text { years } \ldots \ldots \ldots \ldots \\
40-44 \text { years } \ldots \ldots \ldots \ldots\end{array}$ & $\begin{array}{r}9,521 \\
10,629 \\
10,263 \\
9,381 \\
7,893 \\
6,412\end{array}$ & $\begin{array}{l}100.0 \\
100.0 \\
100.0 \\
100.0 \\
100.0 \\
100.0\end{array}$ & $\begin{array}{r}3.7 \\
12.1 \\
26.7 \\
35.3 \\
39.4\end{array}$ & $\begin{array}{r}0.0 \\
* 0.6 \\
3.7 \\
10.1 \\
18.4 \\
21.8\end{array}$ & $\begin{array}{r}* 2.1 \\
6.0 \\
10.3 \\
9.2 \\
12.6 \\
10.8\end{array}$ & $\begin{array}{r}{ }^{*} 0.5 \\
{ }^{*} 0.9 \\
* 1.5 \\
{ }^{*} 1.7 \\
3.1 \\
{ }^{*} 2.9\end{array}$ & $\begin{array}{r}* 1.6 \\
4.9 \\
7.7 \\
6.5 \\
7.0 \\
4.7\end{array}$ & $\begin{array}{l}* \\
* 0.2 \\
* 1.0 \\
* 1.1 \\
* 2.5 \\
* 3.2\end{array}$ & $\begin{array}{l}97.9 \\
89.7 \\
73.9 \\
54.0 \\
33.7 \\
28.0\end{array}$ \\
\hline
\end{tabular}

Women classified as "surgically sterile for noncontraceptive reasons" had sterilizing operations for reasons other than limiting the size of their families. Table 1 shows that 8 percent (about 4.2 million) had had such operations, including 1 percent of never married women, 11 percent of currently married women (or their current husbands), and 14 percent of formerly married women. The percent sterilized for noncontraceptive reasons also was higher for women with children than for childless women.

Women classified as "nonsurgically sterile" said that it was impossible to have a baby for some reason other than a sterilizing operation-such as accident, illness, or unexplained inability to conceive. As of 1982, 0.9 million women ( 2 percent) were classified as nonsurgically sterile. The percent nonsurgically sterile was 1 to 2 percent in each marital status category.

Women classified as "subfecund" said that it was physically difficult for them to conceive or deliver a baby, or that a doctor had told them never to become pregnant again, because of danger to the woman, the baby, or both. In 1982, 5 percent, or about 2.9 million women, were classified as subfecund, including 3 percent of never married, 6 percent of currently married, and 9 percent of formerly married women (table 1 ).

Women or couples who were continuously married (either formally or informally), did not use contraception, and did not become pregnant for 36 months or more were classified as having a "long interval." Although these women reported no known physical problems, they were well beyond any normal period for conception, indicating some impairment to childbearing and possibly sterility. As of 1982, 1 percent of all women, or about 0.6 million women, had a long interval.

The category "impaired fecundity" includes women who were classified as nonsurgically sterile, subfecund, or having a "long interval" since their last pregnancy. About 4.4 million women, or 8 percent, had impaired fecundity. Of these, about 1.9 million were childless and about 2.5 million had 1 or more children (calculated from table 1).

"Fecund" is a residual category consisting of women who were not surgically sterile (and whose husbands were not surgically sterile) and did not have impaired fecundity. In table 1 , 94 percent of never married women were classified as fecund, compared with about 51 percent of currently married and 55 percent of formerly married women. There are two main reasons for this large difference between never married and ever married women: never married women are younger on average than ever married women, and most never married women have never been pregnant or tried to become pregnant. As a result, never married women are much less likely to be 
surgically sterile than ever married women, and have had less chance to develop or discover any fecundity problems.

Table 1 also contains data for all women by age. Differences between age groups also reflect differences in marital status, parity, and other factors. The percent contraceptively sterile increased with age, from 4 percent at ages $20-24$ to 39 percent at ages $40-44$. The percent noncontraceptively sterile also increased with age, especially after age 30 . The percent with impaired fecundity ranged from 2 percent at ages $15-19$ to 13 percent at ages $35-39$. Because both surgical sterility and impaired fecundity are more common at the older ages, the percent fecund declined from 98 among teenagers to 28 among women $40-44$ years of age.

\section{Trends Among Married Couples: 1976 to 1982}

In 1982, as in 1976, the proportions of couples in both categories of surgical sterilization increased with age and both were greater among couples with children than among childless couples (table 2). However, the proportions contraceptively sterile differ sharply by parity at each age while noncontraceptive sterilization is little affected by parity. In both years, impaired fecundity was notably more common among childless women. It also increased with age, especially among childless couples: about half the childless couples 35-44 years of age had impaired fecundity. The increase in impaired fecundity with age was not statistically significant among couples with children in 1982 .

The percent of married couples who were contraceptively sterile increased by half-from 19 percent in 1976 to 28 per- cent in 1982-as shown in table 2. The largest increase occurred among couples with wives 35-44 years of age who had 1 or more children. Changes in the percents surgically sterile for noncontraceptive reasons were not marked and generally were not statistically significant. The proportion of currently married couples who were surgically sterilized (all reasons) rose at a faster rate from 1976 to 1982 than from 1965 to 1976 (table 3): an increase of 10.7 percentage points from 1976 to 1982 ( 1.8 percentage points per year) compared with an increase of 12.4 percentage points from 1965 to 1976 (1.1 percentage points per year).

Overall and among those with children, between 1976 and 1982 the proportions of couples with impaired fecundity decreased, although at 15-24 years of age the decline was not statistically significant. There was no significant change in any of the three age groups in the proportion of childless couples with impaired fecundity (table 2 ).

The proportion fecund decreased from 56 to 51 percent overall, primarily because of the decline from 35 to 26 percent among wives 35-44 years of age with children (table 2). The overall decline in the proportion of childless couples who were fecund (from 73 to 68 percent) was entirely due to the older age composition of childless couples in 1982 compared with 1976; there were no significant declines in the percent fecund in any age group of childless couples.

\section{Infertility Among Married Couples}

"Infertility" is a medical concept for identifying couples potentially in need of medical services to improve their chances of childbearing. When neither partner is surgically sterile, a

Table 2. Number of currently married women $15-44$ years of age and percent distribution by fecundity status, according to parity and age: United States, 1976 and 1982

[Statistics are based on samples of the female population of the conterminous United States. See Technical notes for estimates of sampling variability and definitions of terms. Data for 1982 are preliminary]

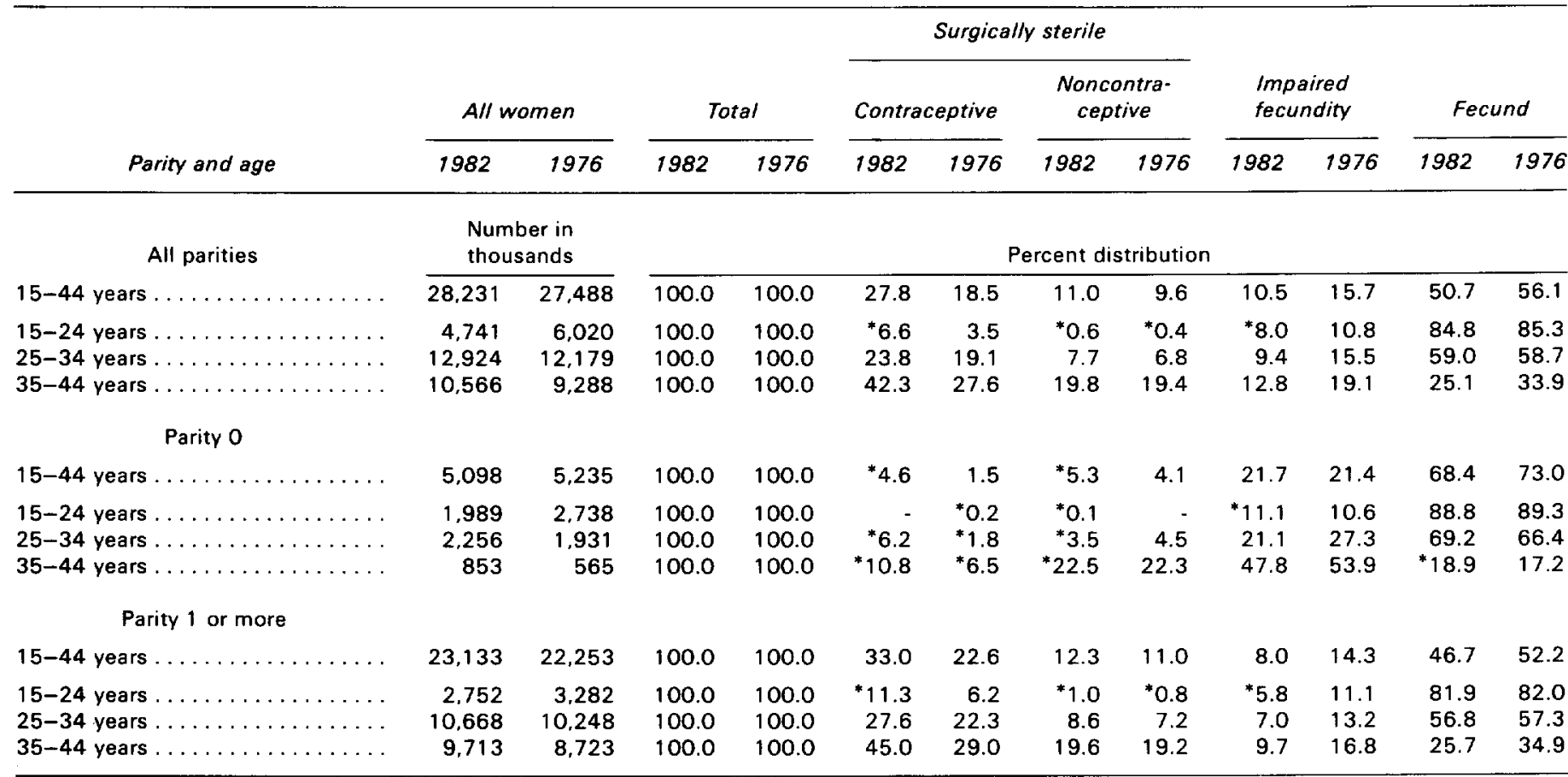


Table 3. Number of currently married women 15-44 years of age and percent distribution by infertility status, according to age, parity, and race: United States, 1965, 1976, and 1982

[Statistics are based on samples of the female population of the conterminous United States. See Technical notes for estimates of sampling variability and definitions of terms. Data for 1982 are preliminary]

\begin{tabular}{|c|c|c|c|c|c|c|c|c|c|c|c|c|c|}
\hline \multirow[b]{3}{*}{ Age, parity, and race } & & & & \multicolumn{10}{|c|}{ Infertility status } \\
\hline & \multicolumn{3}{|c|}{ All women } & \multicolumn{4}{|c|}{ Surgically sterile } & \multicolumn{3}{|c|}{ Infertile } & \multicolumn{3}{|c|}{ Fecund $^{2}$} \\
\hline & 1982 & 1976 & $1965^{1}$ & Total & 1982 & 1976 & 1965 & 1982 & 1976 & 1965 & 1982 & 1976 & 1965 \\
\hline & \multicolumn{3}{|c|}{ Number in thousands } & \multicolumn{10}{|c|}{ Percent distribution } \\
\hline Total $^{3} \ldots$ & 28.231 & 27,488 & 26,454 & 100.0 & 38.9 & 28.2 & 15.8 & 8.4 & 10.3 & 11.2 & 52.7 & 61.6 & 73.0 \\
\hline AGE & & & & & & & & & & & & & \\
\hline $\begin{array}{l}15-19 \text { years. } \ldots \ldots \ldots \ldots \\
20-24 \text { years. } \ldots \ldots \ldots \ldots \ldots \\
25-29 \text { years. } \ldots \ldots \ldots \ldots \\
30-34 \text { years. } \ldots \ldots \ldots \ldots \ldots \\
35-39 \text { years. } \ldots \ldots \ldots \ldots \ldots \\
40-44 \text { years. } \ldots \ldots \ldots \ldots \ldots\end{array}$ & $\begin{array}{r}612 \\
4,130 \\
6,442 \\
6,482 \\
5,783 \\
4,783\end{array}$ & $\left.\begin{array}{l}1,043 \\
4,977 \\
6,443 \\
5,736 \\
4,814 \\
4,474\end{array}\right\}$ & $\begin{array}{r}1,032 \\
4,397 \\
4,953 \\
5,074 \\
10,998\end{array}$ & $\begin{array}{l}100.0 \\
100.0 \\
100.0 \\
100.0 \\
100.0 \\
100.0\end{array}$ & $\begin{array}{l}{ }^{*} 0.3 \\
* 8.2 \\
19.6 \\
43.6 \\
58.2 \\
66.7\end{array}$ & $\begin{array}{r}* 1.0 \\
4.5 \\
16.6 \\
36.2 \\
45.3 \\
49.0\end{array}$ & $\begin{array}{r}* 0.6 \\
3.1 \\
9.5 \\
17.0 \\
22.8 \\
26.8\end{array}$ & $\begin{array}{r}* 2.1 \\
9.7 \\
7.0 \\
7.7 \\
10.2 \\
9.0\end{array}$ & $\begin{array}{r}* 2.1 \\
6.4 \\
9.0 \\
10.3 \\
12.5 \\
15.9\end{array}$ & $\begin{array}{r}{ }^{*} 0.6 \\
* 3.5 \\
6.5 \\
11.6 \\
14.2 \\
20.2\end{array}$ & $\begin{array}{l}97.7 \\
82.1 \\
73.4 \\
48.7 \\
31.6 \\
24.3\end{array}$ & $\begin{array}{l}96.6 \\
89.2 \\
74.4 \\
53.5 \\
42.2 \\
35.2\end{array}$ & $\begin{array}{l}98.9 \\
93.4 \\
84.0 \\
71.3 \\
63.0 \\
52.9\end{array}$ \\
\hline \multicolumn{14}{|l|}{ PARITY } \\
\hline $\begin{array}{l}0 \ldots \ldots \ldots \ldots \\
1 \ldots \ldots \ldots \ldots \ldots \\
2 \ldots \ldots \ldots \ldots \\
3 \text { or more } \ldots \ldots \ldots \ldots \ldots \ldots\end{array}$ & $\begin{array}{l}5,098 \\
5,891 \\
9,042 \\
8,201\end{array}$ & $\begin{array}{l}5,235 \\
5,571 \\
7,638 \\
9,045\end{array}$ & $\begin{array}{r}3,492 \\
4,497 \\
6,878 \\
11,587\end{array}$ & $\begin{array}{l}100.0 \\
100.0 \\
100.0 \\
100.0\end{array}$ & $\begin{array}{r}9.9 \\
17.7 \\
46.8 \\
63.4\end{array}$ & $\begin{array}{r}5.6 \\
8.8 \\
32.3 \\
49.8\end{array}$ & $\begin{array}{r}7.3 \\
7.5 \\
14.2 \\
21.5\end{array}$ & $\begin{array}{r}19.6 \\
10.6 \\
5.0 \\
3.8\end{array}$ & $\begin{array}{r}18.1 \\
12.4 \\
6.0 \\
7.9\end{array}$ & $\begin{array}{r}14.5 \\
17.2 \\
9.3 \\
9.4\end{array}$ & $\begin{array}{l}70.5 \\
71.7 \\
48.2 \\
32.8\end{array}$ & $\begin{array}{l}76.3 \\
78.8 \\
61.7 \\
42.3\end{array}$ & $\begin{array}{l}78.2 \\
75.3 \\
76.6 \\
69.0\end{array}$ \\
\hline \multicolumn{14}{|l|}{ RACE AND AGE } \\
\hline $15-44$ years. . . . . . . . & 25,175 & 24,795 & 23,427 & 100.0 & 38.9 & 29.0 & 15.9 & 8.1 & 9.4 & 10.5 & 53.0 & 61.6 & 73.6 \\
\hline $\begin{array}{l}15-29 \text { years. } \ldots \ldots \ldots \ldots \ldots \\
30-44 \text { years } \ldots \ldots \ldots \ldots\end{array}$ & $\begin{array}{l}10,005 \\
15,170\end{array}$ & $\begin{array}{l}11,217 \\
13,577\end{array}$ & $\begin{array}{r}9,166 \\
14,261\end{array}$ & $\begin{array}{l}100.0 \\
100.0\end{array}$ & $\begin{array}{l}13.7 \\
55.5\end{array}$ & $\begin{array}{l}10.7 \\
44.1\end{array}$ & $\begin{array}{r}5.5 \\
22.3\end{array}$ & $\begin{array}{l}7.4 \\
8.6\end{array}$ & $\begin{array}{r}6.7 \\
11.6\end{array}$ & $\begin{array}{r}4.4 \\
14.3\end{array}$ & $\begin{array}{l}78.8 \\
35.9\end{array}$ & $\begin{array}{l}82.6 \\
44.3\end{array}$ & $\begin{array}{l}90.1 \\
63.3\end{array}$ \\
\hline \multicolumn{14}{|l|}{ Black } \\
\hline $15-44$ years. . . . . . . . . & 2.125 & 2,169 & ${ }^{4} 3,027$ & 100.0 & 36.3 & 21.6 & 14.2 & 13.1 & 18.1 & 16.3 & 50.6 & 60.3 & 69.5 \\
\hline $\begin{array}{l}15-29 \text { vears } \ldots \ldots \ldots \ldots \ldots \\
30-44 \text { years } \ldots \ldots \ldots \ldots \ldots\end{array}$ & $\begin{array}{r}859 \\
1,266\end{array}$ & $\begin{array}{r}993 \\
1,177\end{array}$ & $\begin{array}{l}41,216 \\
41,811\end{array}$ & $\begin{array}{l}100.0 \\
100.0\end{array}$ & $\begin{array}{l}19.7 \\
47.5\end{array}$ & $\begin{array}{r}9.2 \\
32.1\end{array}$ & $\begin{array}{r}6.6 \\
20.6\end{array}$ & $\begin{array}{l}10.9 \\
14.6\end{array}$ & $\begin{array}{l}12.1 \\
23.2\end{array}$ & $\begin{array}{r}4.5 \\
26.1\end{array}$ & $\begin{array}{l}69.4 \\
37.9\end{array}$ & $\begin{array}{l}78.7 \\
44.7\end{array}$ & $\begin{array}{l}88.9 \\
53.3\end{array}$ \\
\hline
\end{tabular}

${ }^{1}$ For method of estimation, see Technical notes.

2The definition of "fecund" used in this table is different from the definition used in tables 1 and 2.

${ }^{3}$ Includes white, black, and other races.

${ }^{4}$ Figures are for races other than white.

couple is classified as infertile if, during the preceding 12 months or longer, they were continuously married (presumed to be sexually active), had not used contraception, and had not conceived. ${ }^{4-6}$ The measure of infertility generally provides lower estimates than impaired fecundity, as in tables 1 and 2 , because it includes only wives who have difficulty conceiving, and excludes wives who are using contraception because a pregnancy would threaten their health. An important advantage of this measure is that we can measure the trend in infertility since $1965,{ }^{1,3}$ as shown in tables 3 and 4 . Not shown in the tables is the duration of infertility, which averaged (median) 27 months in 1982 , with 47 percent of infertile couples having been infertile for 30 months or more.

Changes in the percent infertile between 1976 and 1982 generally were not statistically significant, except for the decline among women 40-44 years of age. However, during the longer period between 1965 and 1982, the proportion infertile showed a statistically significant decline, from 11 percent in 1965 to 8 percent in 1982. This overall decline occurred because the increase in infertility among women under age 30 was more than offset by the sharp decline in the percent infertile among women 30-44 years of age.

The decline in infertility among older women and overall is the result of the large increase in surgical sterilizations. Although it is possible that more women who know they are infertile may have surgical sterilizations, it seems more likely that the increasing use of contraceptive sterilizations reduces the proportions of women who otherwise would find themselves infertile at age 30 and older.

When couples who were surgically sterile are excluded, the percent infertile did not change significantly between 1965 (13 percent) and 1982 (14 percent) (table 4). Among couples who were not surgically sterile, for those with wives aged 20-24 years, the percent infertile increased from 4 percent in 1965 to 11 percent in 1982 . This was the only statistically significant change in any age or parity group in table 4.

Table 3 also contains data by race. The percent classified as infertile was higher among black than white couples in all three survey years; in 1982, 13 percent of black and 8 percent of white couples were classified as infertile. The increase in the 
Table 4. Percent of currently married women 15-44 years of age (excluding surgically sterile) who were infertile by age, parity, and race: United States, 1965, 1976, and 1982

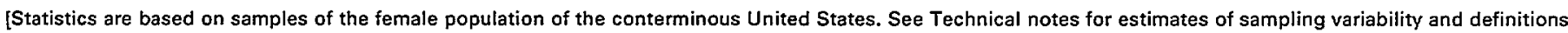
of terms. Data for 1982 are preliminary]

$$
\text { Age, parity, and race }
$$

Total

Age

$15-19$ years

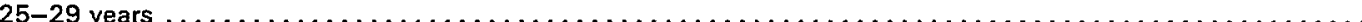

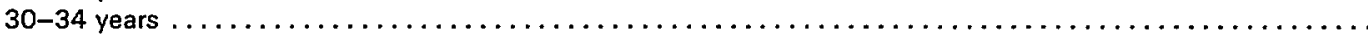

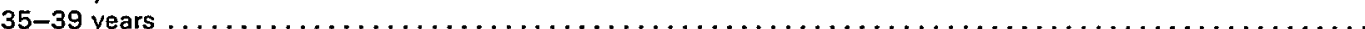

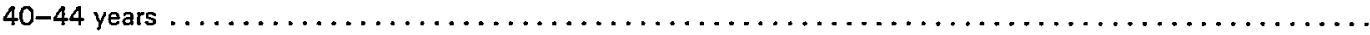

Parity

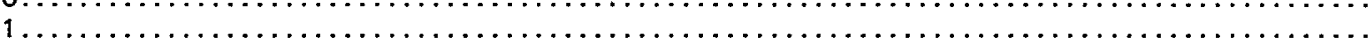

קט,

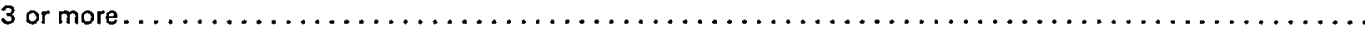

Race

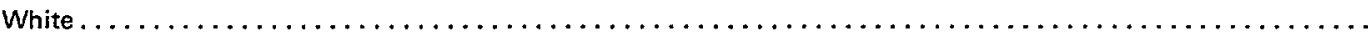

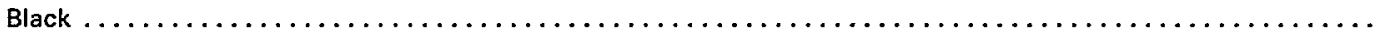

\begin{tabular}{|c|c|c|}
\hline 1982 & 1976 & 1965 \\
\hline \multicolumn{3}{|c|}{ Percent } \\
\hline 13.8 & 14.3 & 13.3 \\
\hline$* 2.1$ & ${ }^{*} 2.1$ & ${ }^{*} 0.6$ \\
\hline 10.6 & 6.7 & ${ }^{*} 3.6$ \\
\hline 8.7 & 10.8 & 7.2 \\
\hline 13.6 & 16.1 & 14.0 \\
\hline 24.4 & 22.8 & 18.4 \\
\hline 27.2 & 31.1 & 27.7 \\
\hline 21.8 & 19.2 & 15.6 \\
\hline 12.9 & 13.6 & 18.6 \\
\hline 9.3 & 8.9 & 10.8 \\
\hline *10.4 & 15.8 & 12.0 \\
\hline 13.3 & 13.3 & 12.5 \\
\hline 20.6 & 23.1 & 19.0 \\
\hline
\end{tabular}

${ }^{1}$ Includes black, white, and ather races.

percent infertile, from 4 to 7 percent among white couples with wives $15-29$ from 1965 to 1982 , was not statistically significant. There was a significant decrease, from 14 to 9 percent, among white couples with wives $30-44$. The percent infertile among black couples $15-44$ did not change significantly be- tween 1965 and 1982 because there was a significant increase at ages 15-29 years ( 5 to 11 percent) and a significant decrease at ages $30-44$ years ( 26 to 15 percent). The changes between 1976 and 1982 for white and black women 15-29 years of age were not statistically significant.

\section{References}

INational Center for Health Statistics, W. Mosher and W. Pratt: Reproductive impairments among married couples: United States. Vital and Health Statistics. Series 23, No. 11. DHHS Pub No. (PHS) 83-1987. Public Health Service. Washington. U.S. Government Printing Office, Dec. 1982.

${ }^{2}$ N. B. Ryder and C. F. Westoff: Reproduction in the United States, 1965. Princeton, N.J. Princeton University Press, 1971.

${ }^{3}$ W. Mosher: Infertility trends among U.S. couples: 1965-1976. Family Planning Perspectives 14(1):22-27, Jan./Feb. 1982.

${ }^{4}$ R. Hatcher, G. K. Stewart, F. Stewart, et al.: Contraceptive Technology 1982-1983, 11 th ed., p. 214. New York. Irvington Inc., 1982.
${ }^{5}$ R. Kleinman and P. Senanayake: Handbook on Infertility. London. International Planned Parenthood Federation, 1979.

${ }^{6} \mathrm{R}$. Ansbacher, M. Shapiro, C. L. Witten, and H. Barber: Forum: Management of infertility. The Female Patient 4(8):26-30, 1979.

${ }^{7}$ U.S. Bureau of the Census: Marital status and family status: March 1965. Current Population Reports. Series P-20, No. 144, tables 1 and 3. Washington. U.S. Government Printing Office, Nov, 1965.

${ }^{8}$ U.S. Bureau of the Census: Fertility of the population: June 1964 and March 1962. Current Population Reports. Series P-20, No. 147, table 1. Washington. U.S. Government Printing Office, Jan. 1966. 


\section{Technical notes}

\section{Survey design}

The National Survey of Family Growth (NSFG) is a periodic survey conducted by the National Center for Health Statistics to collect data on fertility, family planning, and related aspects of maternal and child health. Fieldwork for Cycles II and III was conducted under contract by Westat, Inc., in 1976 and 1982 , respectively.

Personal interviews were conducted with a multistage area probability sample of women 15-44 years of age in the noninstitutionalized population of the conterminous United States. In Cycle II, conducted in 1976, ever married women and never married women with offspring living in the household were eligible for the survey. In Cycle III, all women aged 15-44 were eligible regardless of marital status or the presence of offspring. Women living in group quarters were excluded from the sample in Cycle II but included in Cycle III. Interviews were conducted with 8,611 women in Cycle II and 7,969 in Cycle III. Further details of the sample design of Cycle II are given in the report cited in reference 1 .

Fieldwork for Cycle III was conducted between August 1982 and February 1983. Black women and women aged 15-19 were oversampled. Interviews were conducted by trained female interviewers and lasted an average of 1 hour. The interview focused on the woman's pregnancy history; use of contraceptives in each pregnancy interval; ability to bear children in the future; use of family planning and infertility services; marital history; labor force participation; and a wide range of social, economic, and demographic characteristics.

\section{Reliability of estimates}

Because the statistics presented in this report are based on a sample, they may differ from the statistics that would result if all 54 million women represented by the NSFG had been interviewed. The standard error of an estimate is a measure of such differences. The standard error of an estimated number or percent is calculated by using the appropriate values of $A$ and $B$ from table I in the equations,

$$
\mathrm{SE}_{\left(N^{\prime}\right)}=\left(A+\frac{B}{N^{\prime}}\right)^{1 / 2} \cdot N^{\prime}
$$

and

$$
\mathrm{SE}_{\left(P^{\prime}\right)}=\left[\frac{B \cdot P^{\prime} \cdot\left(100-P^{\prime}\right)}{X^{\prime}}\right]^{1 / 2}
$$

where $N^{\prime}=$ the number of women

$P^{\prime}=$ the percent

$X^{\prime}=$ the number of women in the denominator of the percent

NOTE: $A$ list of references follows the text.
Table I. Parameters used to compute estimated standard errors and relative standard errors of numbers and percents of women, by marital status and race: National Survey of Family Growth

\begin{tabular}{llll}
\hline & \multicolumn{3}{c}{ Parameter } \\
\cline { 2 - 3 } Cycle, marital status, and race & & $\mathrm{A}$ & $\mathrm{B}$ \\
\hline
\end{tabular}

CYCLE III (1982)

\begin{tabular}{|c|c|c|}
\hline $\begin{array}{l}\text { All races and white } \ldots \ldots \ldots \ldots \ldots \\
\text { Black } \ldots \ldots \ldots \ldots \ldots \ldots\end{array}$ & $\begin{array}{l}-0.001097329 \\
-0.000908632\end{array}$ & $\begin{array}{r}39,809.1677 \\
6,346.0484\end{array}$ \\
\hline \multicolumn{3}{|l|}{ All marital statuses } \\
\hline $\begin{array}{l}\text { All races and white } . . . . \\
\text { Black .............. }\end{array}$ & $\begin{array}{l}-0.0003935957 \\
-0.000908632\end{array}$ & $\begin{array}{r}21,306.4134 \\
6,346.0484\end{array}$ \\
\hline \multicolumn{3}{|l|}{ Currently married women } \\
\hline 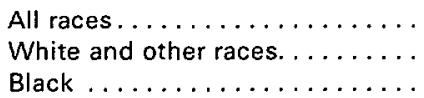 & $\begin{array}{l}-0.000185899 \\
-0.000205624 \\
-0.000631040\end{array}$ & $\begin{array}{l}6,751.0619 \\
7.021 .1665 \\
2,798.6440\end{array}$ \\
\hline
\end{tabular}

Ever married women

The chances are about 68 out of 100 that a sample estimate would fall within one standard error of a statistic based on a complete count of the population represented by the NSFG. The chances are about 95 in 100 that a sample estimate would fall within two standard errors of the complete count estimated. Differences between percents discussed in this report were found to be statistically significant at the 95 -percent confidence level using a 2-tailed $t$-test with 39 degrees of freedom. This means that in repeated samples of the same type and size, a difference as large as the one observed would occur in only 5 percent of samples, if there were, in fact, no difference between the percents in the population.

The relative standard error of a statistic is the ratio of the standard error to the statistic and usually is expressed as a percent of the estimate. In this report, statistics with relative standard errors of 30 percent or larger are indicated with an asterisk (*). These estimates may be viewed as unreliable by themselves, but they may be combined with other estimates to make comparisons of greater precision.

Statistics in this report also may be subject to nonsampling error, that is, errors or omissions in responding to the interview, recording answers, and processing data. The data have been adjusted for nonresponse by means of adjustments to the sample weights assigned to each case. Other types of nonsampling error were minimized by a series of quality control measures as described in reports on Cycle II. ${ }^{1}$

\section{The 1965 National Fertility Study}

The figures on infertility for 1965 in tables 3 and 4 were computed from the 1965 National Fertility Study and were published previously. ${ }^{\mathrm{I}} 3$ The survey design and procedures are described in references 1 and 2 .

Unlike the NSFG, the 1965 National Fertility Study did not include procedures to obtain weighted numbers; therefore, 
approximate numbers of currently married women for 1965 were obtained from population estimates made by the U.S. Bureau of the Census. The weighted numbers shown for 1965 in table 3 differ from those shown for 1976 and 1982 in the following ways: in the 1965 figures, Alaska and Hawaii are included; "black" includes women of all races other than white; and the age range includes currently married women 14 years of age. The population estimates for 1965 are obtained from two reports published by the U.S. Bureau of the Census. ${ }^{7,8}$

\section{Definitions of terms}

Fecundity status-Fecundity is the physical ability of a woman or couple to have children at the time of interview, and refers to women with any number of children, unless classified by parity. It is determined by responses to questions asked in the NSFG interview, not by a medical examination. Fecundity status, as shown in tables 1 and 2 , has three main categories: surgically sterile, impaired fecundity, and fecund. Women were classified as surgically sterile if they (or their current husband) had had a sterilizing operation. Surgically sterile is divided into two subcategories: contraceptive and noncontraceptive. Impaired fecundity is divided into the subcategories nonsurgically sterile, subfecund, and long interval. Women were classified as nonsurgically sterile if they reported that it was impossible for them to have a baby for any reason other than a sterilizing operation; as subfecund if it was difficult or dangerous to have a baby; and as "long interval" if they had been continuously married (formally or informally), had not used contraception, and had not become pregnant for 3 or more years. In tables 1 and 2, fecund is a residual category and means that the woman (or couple) is not surgically sterile and does not have impaired fecundity. The percent of currently married couples with impaired fecundity is higher than the percent in-

NOTE: $\mathrm{A}$ list of references follows the text. fertile because impaired fecundity includes difficulty in conceiving and difficulty or danger carrying to term, whereas infertility includes only difficulty in conceiving. For more detailed discussion of the concept of fecundity status, see the text of this report, and the report cited in reference 1.

Infertility status-Infertility is a medical concept; it identifies couples that may need medical services to improve their chances of having children. When neither spouse is surgically sterile, a couple is considered infertile if, during the previous 12 months or longer, they were continuously married, had not used contraception, and had not conceived. Infertility status, as shown in tables 3 and 4, refers to the categories surgically sterile, infertile, and fecund, where fecund means neither surgically sterile nor infertile.

Age-Age is classified by the age of the respondent at her last birthday before the date of interview.

Race-Race refers to the race of the woman interviewed and is reported as black, white, or other. In Cycle III, race was classified according to the woman's report of the race that best described her. In Cycle II, race was classified by the observation of the interviewer. Cycle III data indicated that results using either method of classification were very similar.

Marital status-Persons were classified by marital status as married, widowed, divorced, separated, or never married. In Cycle II, informally married women-women who volunteered that they were sharing living quarters with their sexual partnerwere classified as currently married. These women constituted about 3 percent of currently married women in Cycle II. To improve the comparability of NSFG results over time and with other sources of data, in Cycle III such women were classified according to their legal marital status. In both cycles, women who were married but separated from their spouse were classified as separated if the reason for the separation was marital discord, and as currently married otherwise.

Parity-Parity refers to the number of live births the woman has had.

\section{Symbols}

-. Data not available

... Category not applicable

- Quantity zero

0.0 Quantity more than zero but less than 0.05

Z Quantity more than zero but less than 500 where numbers are rounded to thousands

* Figure does not meet standard of reliability or precision (30 percent or more relative standard error) 


\section{Recent Issues of Advance Data From Vital and Health Statistics}

No. 103. Use of Services for Family Planning and Infertility: United States, 1982 (Issued Dec. 20, 1984)

No. 102. Use of Contraception in the United States: 1982 (Issued Dec. 4, 1984)

No. 101. 1983 Summary: National Hospital Discharge Survey (Issued Sept. 28, 1984)
No. 100. CAT Scan Use in Short-Stay Non-Federal Hospitals: United States, 1979-82 (Issued Sept. 28, 1984)

No. 99. Health Care of Adolescents by Office-Based Physicians: National Ambulatory Medical Care Survey, 1980-81 (Issued Sept. 28,1984 )

\section{Suggested Citation}

National Center for Health Statistics, W. D. Mosher and $W$. F. Pratt: Fecundity and infertility in the

United States, 1965-82. Advance Data From Vital

and Health Statistics. No. 104. DHHS Pub. No.

(PHS) 85-1250. Public Health Service. Hyattsville. Md., February 11, 1985.

\section{Copyright information}

This report may be reprinted without further permission.

U.S. DEPARTMENT OF HEALTH AND

HUMAN SERVICES

Public Health Service

National Center for Health Statistics

3700 East-West Highway

Hyattsville. Maryland 20782

THIRD CLASS MAIL

BULK RATE

POSTAGE \& FEES PAID

PHS/NCHS

PERMIT NO. G-281

OFFICIAL BUSINESS

PENALTY FOR PRIVATE USE, $\$ 300$

To receive this publication regularly, contact

the National Center for Health Statistics by

calling 301 436-8500 